\title{
EFFECTS OF AUTHORITARIAN AND ETHICAL LEADERSHIP ON EMPLOYEE PERFORMANCE: THE MEDIATING ROLE OF EMPLOYEE COMPETENCIES AND PERFORMANCE MANAGEMENT PRACTICES IN ZIMBABWEAN BANKS
}

\author{
Stewart Musarapasi ${ }^{1}$, Zanete Garanti ${ }^{2}$ \\ ${ }^{1}$ Hons Accounting Nust Zim, MBA, e-mail: stewartmsp@gmail.com \\ ${ }^{2}$ Associate professor, City Unity College Nicosia, Nicosia, Cyprus, \\ e-mail: z.garanti@cityu.ac.cy
}

Received: 9 July 2020 / Revised: 20 July 2020 / Accepted: 29 July 2020 / Published: 30 November 2020

\begin{abstract}
The purpose and objective of this paper is to identify the effects from key selected independent variables namely Authoritarian Leadership (AL), Ethical Leadership (EL), towards a chosen dependent variable Employee Performance (EP). It also studies the mediating roles of two independents that are Employee Competencies (EC), and Performance Management Practices (PMP) when introduced into the model. A survey questionnaire for data gathering was used and issued to respondents that were bank employees on selected commercial banks located in Harare, the capital City of Zimbabwe, and a total of 390 valid responses were gathered. SPSS version 24 was used to analyse the collected data on each variable through demographic, reliability tests, regression analysis, correlation and factor analysis during the validation process of the gathered data. The data analysis outcome showed that all the identified variables were predictors and influential to employee performance, when analysed as individual variables. The management of companies are required to focus on mixing both the leadership element and the competency as a prerequisite for practices and action towards achieving higher performance.
\end{abstract}

Keywords: authoritarian leadership, ethical leadership, employee competencies, performance management practices, employee performance.

JEL code: M10, M54.

\section{Introduction}

Leadership styles in management are a backbone, which drives the organization to perform well. The Zimbabwean economy has been hard hit with recession for half a decade long, and this study will help in revamping the production side of the service industry specifically in the banking sector. The various leadership styles underpin an organization with direction, plans that need to be implemented and critical to mention is motivation to the employees (Alonso et al., 2018). For years in memorial leadership styles illustrated in many ways, however there is always an endless debate on democratic leadership versus autocratic leadership. The two mentioned styles have merits towards the organization's objectives unfortunately; they also have their fair share of demerits (Al Khajen, 2018).

http://dx.doi.org/10.17770/jresd2020vol1.12.5404

This is an open access article under the Creative Commons Attribution 4.0 International License 
The study has an objective to identify the effects from key selected variables that is to ascertain if independent variables Authoritarian Leadership (AL), Ethical Leadership (EL) have an impact towards Employee Performance (EP). The research paper also studies the mediating roles of Employee Competencies (EC), and Performance Management Practices (PMP) when introduced into the model. Normally, mediating roles change the effect result of the independent variables, the outcome will be crucial in relation to the performance of employees in the banking sector in Zimbabwe (Al Khajen, 20018). The main aim of the study is also to explore the impact of each employee performance in the service industry of Zimbabwe, and the banking sector was chosen as the relevant service to undertake this study. The task of the research was carried out through a questionnaire survey to ascertain if the selected variables have an effect towards employee performance, with a big aim of implementing the research outcome. The study was aimed at augmenting performance of employees in the service industry.

There has been a notable research gap, as most researchers concentrated on more discoveries of the democratic leadership styles towards employee performance in the Zimbabwean service sector. This study has been an attribution of less concentration on what effect authoritarian and ethical leadership styles bring to the performance of the employees. This has been an answer and a rejuvenation to the scholarly field since most research work concentrates on variables of democratic styles of leadership (Al Khajen, 2018). Mediating roles of employee performance in the Zimbabwean banking sector were considered in this study, namely Employee Competencies and Performance Management Practices.

The study targeted the banking sector in Zimbabwe with the primary reason of them being the frontline points of link for economic development through linking the local citizenry, first internally and then externally on dealings with the world, for economic development. The "Zimbabwe is open for Business" mantra echoed by the government in the new dispensation from November 2017, places especially banks at the frontline for capital injection and trade in the economy. Ndlovu and Sigola (2013) highlighted that banks in Zimbabwe have headquarters in the capital city, Harare, a strategic positioning considering the high clientele levels as well as the location of the headquarters for most parastatals and government ministries. The increase in banks in Zimbabwe from nine at independence in 1980 increased competition, as customers have a vast range to choose from with the liberalization of the banking sector however being tainted by a high bank failure rate which leaves consumers stranded and unable to recover their savings and investments. 


\section{Literature Review and Conceptual Framework}

Employees are the human capital and most valued asset in almost all business organizations. They can uphold the organization's reputation, which in return boost the profitability of the firm and or break it in disrepute. Organizations have a huge avenue of tailor making the performance of the employees to a direction, which makes the goals and objectives of business to be achieved (Audenaert et al., 2019). The study has a theoretical framework basing on similar research articles by previous scholars and elaborations of every variable of the study towards the outcome of validity if the variables selected worth on positively affecting the banking sector employee performance of Zimbabwe (Ndlovu \& Sigola, 2013). The demographic aspect contributed immensely to the findings of the study, as employees who have been at the same bank for some years proved to have higher performance and skills than newly promoted (Alsabbah, \& Ibrahim, 2014).

\section{Authoritarian Leadership}

Authoritarian leadership also referred to as autocratic leadership, is considered "a very directive leadership approach in which leaders strive to control subordinate behaviour". Though this approach is criticized by practitioners and academics, some cultures mainly used this leadership style especially in the Asian region by concentrating power and authority on just the leader who has a domineering character which has negative implications (Shena et al. ,2018).

As cited in Igbaekemen and Odivwi (2015), define an authoritative leader as "one who is very conscious of his position and has little trust or faith in the subordinates, feeling that pay is just a reward for work and that it's the only reward that can motivate and the leader gives orders and insists the followers follow". To clarify the scenario, Kiazed et al. (2010) alert that autocratic leadership does not imply the mistreatment of followers and is not necessarily synonymous with authoritarian personalities but people who just assume they have to assume dominating traits when they get into leadership positions. That being the case some may employ destructive leadership with negative outcomes associated with abuse and the negative leadership behaviour, thus making it disastrous (Harms et al., 2018).

The shortcomings cited by the same and others e.g. Ludeke and Kruger (2013), Jugert et al. (2009) also in the listing were: The followers fail to take pride in accomplishing goals, Deprivation of self-development and selfactualization among the followers, it annoys followers who then turn into not 
being loyal and cooperative, there is lack of continuity management as no successors are nurtured, Lack of innovation results from the trait of rigidity.

\section{Ethical Leadership}

Ethical leadership, considered more participative is defined as "the demonstration of normatively appropriate conduct through personal actions and interpersonal relationships, and promotion of such conduct to followers through communication, reinforcement and decision making", according to Brown et al. (2005). Brown et al. (2005) suggest that normatively appropriate behaviour includes honesty, care, fairness, and trustworthiness which emphasize it is legit and credible, exposing any rot. Asika (2004), Brown et al. (2005) elaborate that reinforcement involves rewarding ethical behaviour and instilling discipline to discourage unethical behaviour.

Trevino and Harrison (2005) cited in Walumbwa et al. (2011) proposed the suggestion that ethical leadership results in positive behaviours/attitudes in employees and effective organizational functioning, while in dispute other researchers associate it to "pro-social" and "negatively deviant behaviours". This attractiveness of ethical leaders as credible role models is indicated to enhance effectiveness beyond their authority and status (Walumbwa et al. 2014; Brown \& Trevino, 2006; Brown, 2005).

\section{Employee Performance}

Otoo (2013) citing Mathias and Jackson's (2009) definition of employee performance "the performance associated with output quality, output timeliness, participation and attendance on the job, efficiency and effectiveness of completed work". Organizational performance hinges on individual employee performance on issues of work efficiency, efficient planning, creativity, innovation and commitment (Mastrangelo et al., 2014; Otoo, 2013; Harvey, 2008).

The first definition "the process of assessing the proficiency with which a reporting entity succeeds, by the economic acquisition of resources and their efficient and effective deployment, in achieving its objectives. Performance measures may be based on non-financial and financial information". From a second perspective, it is "the process of developing measurable indicators that can be systematically tracked to assess progress made in achieving predetermined goals and using such indicators to assess progress in achieving these goals." Kwaako et al. (2012) and Harvey (2008) also support that corporate goals can be achieved by management applying a proper performance management system to direct employee performance; financial and non-financial measures of service quality, resource utilization, 
competitiveness, automation, customer satisfaction, and organizational agility.

\section{Employee Competencies}

Diamantidis and Chatzoglou (2019) stress the value of employees with diverse skills as assets to organizations, as they can handle many current and future job requirements. Emmerling and Boyatzis (2012) define employee competence as the capability or ability that leads to effective performance. In the plural, competencies have to be developed in employees to enable them to meet their job demands, as the employees that have a variety of competencies meet their job demands with ease (Mukonoweshuro \& Sanagura, 2016).

VanEsch et al. (2016) posit that in this light human capital is a critical resource for firm performance and is valuable for its unique, firm-specific, and unique expertise. They also encourage firms to take a big role in equipping employees with the requisite competencies over and above selective staffing which recruits and selects employees bearing the requisite skills and competencies in support of the firm strategy. The employee competence begins with the Human Resources section's competence in selecting, staffing and training, development, rewards, performance appraisal that helps an organization to maintain adequate competencies instrumental to the firm's strategy. The skill sets that can entail employee competence include technical, behavioural, business, and specialty trade knowledge. Yang and Lin (2009) state that extensive hiring competencies that involve thorough searching, careful screening, thorough interviews that aid the selection of the most competent employee should also be complemented by appropriate and extensive training and development to widen their knowledge and competencies and enhance the achievement of goals.

\section{Performance Management Practices}

Performance management practices according to Van Esch et al. (2016) relate to the imparting and improvement of competencies: training and development, selective staffing, rewards, performance management, and self-managing teams. Internal development of knowledge and skills of employees placing them in a position to develop firm-specific competencies and influence employee behaviour and attitudes and (Pulakos, 2004) states that effective training aids in the accomplishment of goals and can be through classroom training, workshops, web-based training or on the job training by other seasoned practitioners. 


\section{Theoretical Framework Leader-Member Exchange (LMX)}

This is a theory developed by Bandura $(1977,1986)$. According to Brown and Travino (2006), which states that the effectiveness of workers is influenced by the quality of leader-member exchange (LMX) that is how an employee and the immediate supervisor relate. LMX is therefore the quality of these relationships. Interactions and experiences among the two determine the quality of relationships developed but the leader being the stronger value in the exchange, while the member is the weaker influencer of the relationships are formed. This is to say that more interaction between the members with the managers strengthens the relationship and its quality. When a manager treats employees fairly, they feel the obligation to reciprocate or return the treatment by putting more effort on the leader's behalf which results in high quality from the boosted motivation and consequently high performance (Walumbwa et al. 2011). The leader should therefore consider the nature of relationships they have with their followers, as the degree of emotional support and resource sharing is important for optimum employee performance.

\section{Social Learning Theory (SLT)}

The Social Learning Theory (Bandura, 1977) clarifies how leaders influence follower behaviour hence their performance which relates to the vital importance of leadership qualities and traits. The basis of SLT is that "people learn by paying attention to and emulating the attitude, values, and behaviours of attractive and credible models ... most leaders possess authority because of the positions of status they occupy but attractiveness involves much more than authority and status." Therefore, leaders that fairly treat others and demonstrate concern and care become attractive to followers who pay more attention to them and want to emulate the positive traits (Bandura, 1986) as cited in (Brown \& Travino, 2006).

Igbaekemen and Odivwri (2015) opine that an opposite leadership style should therefore reward employee effort hence placing more value on them. The leader should encourage integrity, honesty, commitment, participation, and ownership. Authoritative leadership would not work according to this philosophy, as decision making would need to be decentralized, employee initiatives encouraged, and cross-functional management implemented. 


\section{McGregor's Theory X and Y}

Theory posits that the leadership style adopted by managers takes influence from their perception of their subordinates who may either be in category X or category Y (Igbaekemen \& Odiviwri, 2015). Theory X assumptions are that humans generally dislike work and need to be directed, coerced, or threatened with punishment for them to perform towards the achievement of goals. Despite wanting security, humans still prefer being directed and would avoid responsibility at all costs and have little ambition for results. This view is synonymous with management who would adopt an authoritarian leadership style. In contrast, Theory Y assumptions are that the employees are motivated to work, they make application of physical and mental effort comfortably just rest and therefore do not need external control and threats to get them to put effort towards organizational goals, as the employees will apply a commitment to their performance. The employees would, therefore, commit to the objectives through rewards for their effort and under proper conditions would seek more responsibility; therefore, responsibility can be decentralized.

This theory reflects that leadership approach choice would be inclined to the leaders' perception of the people under their leadership; additionally, the leadership style adopted also has an impact on employee performance and commitment both positively or negatively. McGregor then suggested to management that to achieve effectiveness, they had to recognize the dignity and capabilities/ limitations of the team members and apply appropriate behaviours as demanded per case (Igbaekemen \& Odiviwri, 2015).

\section{Contingency Approach}

The contingency approach stresses that no leadership style can be best and applicable in all situations or environments, as solutions to different challenges depend on specific situational and environmental factors. Therefore, the leadership style to adopt was contingent upon the leadermember relationship, power, position as well as the structure of the task (Miles, 2007). While suggesting that to be effective, a leader could not afford to stick to one management style for all situations. Ejomabo (2015) highlighted that even the maturity of a leader determined the leadership approach they employed because of issues of experience, confidence, authority among others.

Ejambo (2015) and Miles (2007) concurred that the effectiveness of any leadership style was not about its structure, which meant to say that no leadership style said to be better than the other styles. However, different situations, particular leadership styles would be more effective, for example, 
an arrogant team would need an autocrat depending on the work involved, otherwise a charismatic leader to woe their attitudes and motivate commitment and higher performance. Leadership success relied on the proper assessment of the situation which would lead to the application of an appropriate leadership approach for desired outcomes to be achieved.

The other perspective of the contingency approach according to Miles (2007) is that in terms of traits, suitability, maturity or approach, the type of leader appropriate for a situation was contingent upon situational factors. The situation per particular scenario determined the best incumbent leader.

\section{H1: Authoritarian leadership has a positive effect on employee performance.}

The view of the Zimbabwe economy coming from a decade long inflation scenario, made this equation to be one of the best suit to the study, specifically in the banking sector of Zimbabwe. Otoo et al. (2019) view authoritarian leadership as constituting an individual's perception or positive emotional status arising from job experiences and personal appraisal/evaluation of their job or environment, with the performance measures being planning of work, innovation and creativity, the efficiency of work, and application of effort. Harms et al. (2018) indicate it is however apt to have negative effects in the form of low team functioning and performance as a result of the negative opinions or perceptions of leaders on followers, leading to poor communication and distance hence low leader-member exchange. On the contrary, its outcomes on employee performance can sometimes be against common perceptions (Ludeke, 2016). The first hypothesis is drawn from this background.

\section{H2: Ethical leadership has a positive effect on employee performance.}

Ethical issues in leadership of the service sector has been hindering the success of performance of employees, not only performance of employees in the Zimbabwean banking sector but the whole spectrum of the Zimbabwean industry and Africa at large. Also cited in Otoo et al. (2019), Mathias and Jackson (2009) and Rich et al. (2010) opine that employee performance is related to output quality, quantity, and timeliness, work attendance as well as efficiency and effectiveness in completing work, as the engaging trait of ethical leaders guarantees enhanced organizational performance through employees' dedication. Brown et al. (2006) indicated this expectation of positive follower attitudes towards ethical leadership was derived from the perceived leader honesty, fairness, trustworthiness, care, and concern for employees as well as principled decision making. Walumbwa et al. (2011), in the reservation, suggested examining the claimed benefits about 
performance to appropriately structure ethics initiatives or programmes. The second hypothesis follows up on these perspectives.

\section{H3: Employee competencies have a positive effect on employee performance.}

Recruitment of relevant employee staff in the service industry in Zimbabwe has been integral since the country attained its independence in 1980. Buil et al. (2019) opines that although leadership styles adopted by managers affected employee performance, the personality traits of frontline employees shaped their attitudes within their job descriptions and fore extended effort performance. Such being the case, it is stressed that not just the competencies of followers are critical for organizational performance, but also the competencies of frontline employees in the form of middle and operational managers who are key for employee performance. In a service industry, such confident employees will positively respond to customer requests and concerns, thus displaying better performance. Higher employee skills flexibility provides a competitive edge and a high level of employee competencies and guarantees high employee performance (Buil et al., 2019). This is hypothesized as:

H4: Performance management practices have a positive effect on employee performance.

The Zimbabwean banking sector, like any other business sector, was a point of interest to this study in checking the practices performed by the management of banks if it has an impact of the performance of employees. In the late 1990s, the Zimbabwean banking sector was hard hit with weaker management practices resulting in a number of commercial banks being liquidated and closed. Wong et al. (2019) opine that employee performance can be improved by the application by the management of various performance management practices. Performance management practices such as training, inspections, monitoring, performance appraisal are indicated to have an impact not only on employee performance but on the organization's environmental, economic and social performance, as the value chain monitoring is enhanced (Paulraj et al., 2015).

\section{H5: Authoritarian leadership has a positive effect on employee competencies.}

Employee competencies are critical to the Zimbabwean economy's resuscitation, as the view of the Zimbabwean economy coming from a decade long inflation scenario made this equation to be one of the best suit to the study, specifically in the banking sector of Zimbabwe. There are facets of 
employee competency which are responsive to authoritarian leadership, according to (Wang \& Wang, 2018). Employee competencies entail individual employee innovation and being multi-skilled, which may be suppressed through an authoritarian approach which is more restrictive, as the leadership style emphasizes control. They indicated that good leadership was largely measured by giving followers room to innovate in various capabilities which authoritarian leadership has a rather negative influence. Authoritarian leadership stifles employee motivation, and innovation is suppressed because of fear of punishment and hence the status quo is maintained by not offering ideas or advice. A negative relationship between employee creativity and authoritarian leadership and performance can be improved through the selection of already skilled and competent employees, and increasing communication and team-building processes that build team spirit and enhance employee creativity (Wang et al., 2007).

H6: Ethical leadership has a positive effect on performance management practices.

Brown et al. (2006) states that the dependability of ethical leaders and their motivation, care, and concern for followers and society nurtures effective performance management practices, as they attract and keep the follower's attention towards the organizational goals. Ethical leaders are therefore in this case prone to applying performance management practices which are fair and considerate in the form of clear, consistent principles and standards that they apply to themselves just the same way they apply them to followers. Brown et al. (2005) propose a positive relationship of ethical leadership against performance management practices, indicating that legitimacy is observed for performance management practices applied by ethical leaders as mentors from whom followers learn and emulate practices, attitudes and behaviours, as counterproductive, and antisocial behaviours that are harmful to the organization are avoided because of influenced commitment by reciprocating the leader. From these perspectives, the sixth research proposal is derived.

H7: Employee competencies have a positive mediating effect on authoritarian leadership to employee performance.

H8: Performance management practices have a positive mediating effect on ethical leadership to employee performance.

Ethical issues in leadership of the service sector has been hindering the success of performance of employees, not only performance of employees in the Zimbabwean banking sector but the whole spectrum of the Zimbabwean 
industry and Africa at large. Recruitment of relevant employee staff in the service industry in Zimbabwe has been integral since the country attained its independence in 1980. The Zimbabwean banking sector, like any other business sector, was a point of interest to this study in checking the practices performed by the management of banks if it has an impact of the performance of employees. In the late 1990s, the Zimbabwean banking sector was hard hit with weaker management practices resulting in a number of commercial banks being liquidated and closed.

\section{Methodology \\ Research Design and Approach}

A positivist approach was taken in the deductive research. O'Leary (2005) and Crosssman (2013) state that it is possible to objectively study and explain reality by generating hypotheses through quantitative data that can be statistically analysed such that the observations can be repeatable. A deductive research approach was taken which entails deriving a hypothesis from theory, observing, confirming, or rejecting the hypothesis. As such a quantitative research choice was made, as it focuses on verifying the hypothesis using the data gathered by collecting ratings and verifying user acceptance and deducing results thereon. The focus of quantitative research is to verify a hypothesis of large amounts of data in a deductive manner (O'Leary, 2005). According to White (2000), quantitative research is used to deduce laws, generalizations and relationships between variables as such its selection for this research which seeks to study the impact of authoritarian leadership and ethical leadership as well as the mediating variables employee competencies and performance management practices - on employee performance. All measurement instruments for this study were obtained from relevant previous studies.

\section{Study sample and sampling methodology}

The study was on various commercial banks in Zimbabwe's capital city Harare. This case study design, according to Saunders et al. (2007) and Crosssman (2013) involves an extensive study of a real-life case or case context by restricting the number of cases or settings to study. The scientific sampling method was used by employing probability sampling methods. A stratified random sample was selected through which the population was divided into relatively homogeneous groups called strata, in Harare, Zimbabwe, involving a target sample was 400 participants from 20 bank branches in Zimbabwe. Given a large number of banks in the country as well as their various branches, it would be a mammoth task to have a fully 
representative sample and Colin Fisher (2004) buttresses this assertion by stating that the problem is that no sample can be guaranteed to be fully representative. Dane (1990) states that ordered criteria are used in systematic sampling to select elements from a randomly arranged sample frame by choosing the nth element in the sample frame. For the validity of the sample, the list was arranged hierarchically giving equal chances to all levels to participate. Questionnaires administered in English were distributed within 20 bank branches in Harare and an overall response rate of $86.67 \%$ was achieved. Questionnaires ensured the anonymity of respondents and the participant's responses are not influenced by the researcher (Mitchell \& Jolley, 2010).

\section{Data analysis Demographic Statistics}

The current study sample consisted of bank employees. The greatest number of participants came from the age group between $26-35$ years old (42.1\%; $\mathrm{N}=164$ ). While the age group which had the lowest respondents was between the range of 56 and above years old (4.1\%; $\mathrm{N}=16)$.

Females had the highest response rate of $52.8 \%$, whilst males had a response rate of $47.2 \%$. The researcher distributed the questionnaires to both gender males and females. There was no bias in the distribution of the questionnaire towards gender.

The majority of bank employees who responded the questionnaire were those in the group classified as other (38.5\%; $\mathrm{N}=150)$ which had respondents with under combined qualifications both at undergrads and post-graduation qualifications, this reflected that the majority of the participants were knowledgeable on the study topic and able to provide informed and objective responses.

The majority of respondents were having an employment period between 0 - 5 years with the same bank (51.3\%; $\mathrm{N}=200)$. This experience is valuable for the gathering of authentic representative research data, as employees had a reasonable period at their current employment.

\section{Factor Analysis}

Kaiser-Meyer-Olkin's measure on sampling value adequacy showed 0.771 ; it is considered acceptable, as it is above 0.5 as suggested and recommended by Kaiser Kaiser (1974), with also Bartlett's Test of Sphericity which illustrates the relationship amongst variables. It indicates the significance value of 0.000 which is acceptable, as it is below 0.05 . It is acceptable as significant according to Snedecor and Cochran (1983). This 
translates that the sampling measurement and the variable were having a significant relationship.

\section{Reliability Test}

All variables (AL, EL, EC, and PMP) were tested with Cronbach's Alpha and were accepted as suggested by (Pallent, 2007), that anything above $60 \%$ is acceptable. AL was $66.7 \%$, EL 72.3\%, EC 75.1\% and PMP was $76.5 \%$. This also proved that the data gathered was reliable, as it passed the reliability test through Cronbach's Alpha.

\section{Correlation Analysis}

Correlation in SPSS in data analysis illustrated the direction and strength of the linear relationship amongst variables. The study variables were paired by SPSS, making it possible to identify which had the best linear relationship amongst two different variables.

Cohn (1988) provided a guideline, which makes it easier to interpret the correlation analysis results as follows; 0.10 to 0.29 indicates a small correlation, 0.30 to 0.49 indicates a medium correlation, 0.50 to 1.0 indicates a large correlation. The results showed that two strong variables with the highest correlation were PMP and EL which had a Pearson correlation of $0.718(71.8 \%)$, and EP and EC which showed a strong Pearson correlation of 0.691 (69.1\%), EC and EL had a medium correlation of 0.398 (39.8\%), whilst the other remaining correlations were low.

\section{Regression Analysis}

The most interesting area of the regression analysis was on the mediating roles when they were added to the SPSS data analysis when EC explained the EP as a mediating variable, (c) value of the $\mathrm{R}$-square is 0.493 which demonstrate that $49.3 \%$ of the EC explained the EP. This was the highest correlation relation of all the variables, EC was significantly accepted for positively influencing employee performance in the Zimbabwean banking sector.

The linear regression determined that all variables on an individual basis had P-values which were 0.000 that is less 0.05 , which was considered as statistically significant as suggested by Pallent (2007). The linear regression was significantly accepted, as it met the below 0.05 measurement. This meant that of the chosen independent variables, all of them were 
relevant in positively affecting employee performance in the banking sector of Zimbabwe.

The standard beta of EC became high at 0.871 , showing the increased influence EC has as a mediating variable. Also signifying that EC qualified to be a mediating variable.

Lastly, when the two mediating variables EC and PMP were added on the third scenario, EL has become (not significant) with a negative standard coefficient beta of -0.031 from -0.028 and (not significant) with a $28.9 \%$ way above 0.05 . PMP as a mediating variable proved (not significant) and rejected as a mediating variable with $9.10 \%$ which is outside the limit of 0.05 . EC has a standard beta coefficient of 0.869 , the highest beta and significant 0.000 , which means EC qualified as a mediating variable and it changed the direction of EL changing from -0.028 to -0.031 , which made EC the only outstanding mediating variable to be considered as statistically significant as suggested by Pallent (2007).

\section{Discussion and conclusions}

In the service industry, there is direct contact of employees with the clients, as the product presents a need for highly motivated, hospitable rather than hostile reception for repeat business, and impressive. Concerning corporate image, customer satisfaction, and service quality in banks, Makanyeza and Chikazhe (2017) enlightened that these had positive direct effects on customer loyalty and they were all interlinked, which made the need for this study to be carried out on the basis of performance of employees in the banking sector of Zimbabwe.

The main goal of each organization is to maximize returns, and this is achieved mainly through employee performance which therefore needs to be enhanced (Khovera \& Wechtler, 2018). This study sought to establish the relationship of various factors Authoritarian Leadership (AL), Ethical Leadership (EL), Employee Competencies (EC), and Performance Management Practices (PMP) on Employee Performance (EP).

H1 proposed a positive relationship between AL and EP, which was confirmed by empirical evidence by other researchers as well as research findings from this study. Wang and Guan (2018) confirmed the positive relationship between $\mathrm{AL}$ and $\mathrm{EP}$, through the learning goal orientation. Ludeke (2016) highlighted that AL outcomes on EP are positive with trust, supportive, and unselfish attitude being prevalent in most workplaces the banking sector included. The study proved that at times, performance can be brought through aggressiveness and hostility, which by common perceptions of authoritarian leadership is viewed, are dominant. (Chua et al., 2018) also established that AL positively impacted EP, as the leader strongly took 
charge of the group, assigning tasks and establishing strict timelines for completing tasks.

$\mathrm{H} 2$ proposed a positive effect of EL and EP which the research findings also affirmed in the Zimbabwean banking sector. A positive relationship between EL and EP was established. Brown et al. (2006) indicated that positive follower attitudes overly had a positive impact on performance. Rich et al. (2010) also concluded that EL guaranteed enhanced EP hence a positive relationship between the two, emanating from the dedication of employees emotionally and physically when they are engaged in decision making and planning. Employees got enthused to apply extra effort to their duties. Walumbwa et al. (2011) concluded a significant positive singular relationship between EL and EP and also based on employee perception and organizational identification in line with the issue of fairness.

H3 proposal was a positive relationship between EC and EP. In the study of Zimbabwean banks, a positive relationship between EC and EP was derived. It was revealed that the competence of employees positively affected their performance. A study by Sendawula et al. (2019) and Alsabbah and Ibrahim (2014) concluded a significant positive relationship between EC and EP hence emphasizing the need for managers to have thorough selection processes for employee engagement as well as policies for staff development to improve EC. Buil et al. (2019), in concluding a positive relationship between EC and EP, stated that higher employee skills flexibility provided a competitive edge and high level of employee competencies guaranteed high employee performance.

H4 proposed a positive effect of PMP on EP, which was however discarded as null through research findings despite studies indicating that PMP were tools that had the potential to influence employee performance. Alsabbah et al. (2014) concluded the absence of a positive link between PMP and EP, as PMP were not able to influence EP, except for a partial positive mediating effect of particular training on EP; otherwise, there was no correlation between PMP and EP. Sendawula et al. (2019) however clarified that certain PMP could indeed result in positive outcomes in EP for the organization if applied. Gurbuz (2009) highlights that PMP does not apply to all contexts and is also not appropriate for all employees hence the lack of relationship between PMP and EP. The positive correlation between PMP and EP was established to be underpinned by the social exchange model, ability, motivation and an opportunity framework from a study by Li et al. (2017).

$\mathrm{H} 5$ proposed a positive relationship between $\mathrm{AL}$ and $\mathrm{EC}$ and the findings show some positive correlation between the two. The relationship is not strong according to the scale but significant. Iqbal et al. (2015) sight that with an authoritative leader, inferiority is felt by employees in doing their jobs and 
in making decisions hence the leaders alone possessing the authority to take those decisions where the employee feels inferior. Far et al. (2007) highlighted that certain factors strengthen the effects of AL on EC such as power distance, cultural values, and level of employee and hence resulting in a positive relationship between AL and EC. Kalu and Okpokwasili (2018) stated that though an authoritative leadership style tends to limit the responsibilities and creativity of subordinates, their competencies were improved from learning from the leader. A conclusion by Chua et al. (2018) highlighted that AL positively impacted EC in that as employees concentrated on performing certain specific tasks and not decision making, they became highly skilled in the specific task that is, in firm-specific competencies.

The sixth hypothesis, H6, proposed a positive link between EL and PMP. Brown et al. (2005) concluded a positive relationship between EL and PMP, citing that the legitimacy was observed for performance management practices ethical leaders applied as role models.

The seventh hypothesis, H7, proposed a positive mediating effect of PMP for EL on EP. Brown et al. (2005) propose a positive relationship between EL and PMP, which these study findings have rejected in the Zimbabwean banking sector as well as some studies highlighted above. A positive mediating role of PMP for EL on EP was not validated by this research, and Sendawula et al. (2019) highlight the situational effect of the various PMP tools for which an umbrella effect/ correlation cannot be claimed.

H8 proposed a positive mediating effect of EC for AL on EP. Far et al. (2007) highlight however that certain factors influence AL effects on EC such as power distance, cultural values, and level of employee. The study results reflected AL as not a factor of significance for EP when EC was introduced as a mediating variable. EC independently held a very high positive correlation with EP. The role of EC as a mediating factor for a positive relationship between AL and EP is denounced by Sendawula et al. (2019), as they discard its mediation effect and uphold its effect as an independent factor that positively enhances EP for any leadership approach applied.

The main objective of the study was to identify the positive and/or negative effect of various selected independent variables towards the employee performance in the Zimbabwean banking sector (Alonso et al., 2018). Employee competencies, one of the two mediating variables, had the highest significance acceptability at $86 \%$ when it was added as a mediating role to the model (Al Khajen, 20018). It was confirmation of the higher literacy rate which Zimbabwe has in the African continent. It also proved that the skills of an employee have a huge effect on the performance of the output, as was the case in the banking sector of Zimbabwe.

The recruitment process of employing staff personnel in the banking sector of Zimbabwe is commendable, as this study attested to the data 
findings (Audenaert et al., 2019). The unique aspect of the findings of this study on Zimbabwean banks' leadership styles is the element of the role employee competencies, which was regarded as the chief prerequisite requirement compared with other parts of the world such as the United States of America where they prefer experience-superseding qualifications of the recruitment of staff (Albino, 2018). The Zimbabwean banking sector has been proved by the study to be one of the few African with outstanding employee standard performance as supported by the researched data (Wang \& Guan, 18).

The study qualified Employee Competencies as playing a positive mediating role for Employee Performance, while it proved insignificant hence disqualifying Performance Management Practices as a mediating factor for Employee Performance (Asika, 2004).

\section{Limitation and Future Research}

The study did not consider the comparative effect of EC and PMP on both $\mathrm{AL}$ and EL, which is an extension that could be considered for further study, as it could provide the greatest correlation between the management approach and employee performance and overall organizational performance. Another recommended area for further study is the corroboration of literature on the roles of leadership styles, EC and PMP on $\mathrm{EP}$ as well as the mediating roles of EC and PMP to establish the major reasons for the divergence in the findings concerning the correlation of the factors.

\section{References}

1. Al Khajeh, E. H. (2018). Impact of leadership styles on organizational performance. Journal of Human Resources Management Research, 2018, 1-10.

2. Albino, G. (2018). Technical and behavioral competencies on performance evaluation: Petrek leaders' perspectives. Sage Open, 8(2), 1-12.

3. Alm, J., \& Embaye, A. (2013). Using dynamic panel methods to estimate shadow economies around the world, 1984-2006. Public Finance Review, 41(5), 510-543.

4. Alonso, A., Dorsey, D. and Handson, R. M. (2018). Performance Management That Makes a Difference: An Evidence based Approach. Alexandria: SHRM.

5. Alsabbah, M. Y., \& Ibrahim, H. (2014). HRM practices and employee competence: A general system perspective. International Journal of Business, Economics and Law, 4(1), 11-17.

6. Arora, D. (2018). Seven Human Resource Competencies That Drive Company Success. Retrieved from: https://www.entrepreneur.com/article/323137

7. Asika, N. (2004). Business Organisations and Management. Makuganu and Brothers Enterprise.

8. Audernaert, M., Decramer, A., George B., Veschuere, B.and Waeyenberg, T. V. (2019). When employee performance management affects individual innovation in public 
organisations: the role of consistency and LMX. The International Journal of Human Resource management, 30(6), 815-834.

9. Black, T. R. (1999). Doing quantitative research in social sciences. An intergrated approach to research design, measurement and statistic. Thousand oaks: SAGE publications.

10. Boselie, P., \& Paauwe, J. (2005). Human Resources Function Competencies in European Companies. Personnel review, 34(5), 550-566.

11. Brown, M. E., \& Treviño, L. K. (2006). Ethical leadership: A review and future directions. The leadership quarterly, 17(6), 595-616.

12. Brown, M. E., Treviño, L. K., \& Harrison, D. A. (2005). Ethical leadership: A social learning perspective for construct development and testing. Organizational behavior and human decision processes, 97(2), 117-134.

13. Buil, I., Martínez, E., \& Matute, J. (2019). Transformational leadership and employee performance: The role of identification, engagement and proactive personality. International Journal of Hospitality Management, 77, 64-75.

14. Butts, M., Vandenberg, R., DeJoy, D., Schaffer, B., \& Wilson, M. (2009). Individual Reactions to High Involvement Work Processes: Investigating The Role of Empowerment and Perceieved Organisational Support. Journal of Occupational Health Psychology, 14(2), 122-136.

15. Chua, J., Basit, A., \& Hassan, Z. (2018). Leadership styles and its impact on employee performance. International Journal of Accounting \& Business Management, 6(1), 8094.

16. Crosssman, A. (2013). Sampling Methods. Retrieved from StatPac. Inc.: http://www.statpac.com/surveys/sampling.htm

17. Dane, F. C. (1990). Research methods (Vol. 120). Pacific Grove, CA: Brooks/Cole Publishing Company.

18. Decramer, A., Audenaert, M., Van Waeyenberg, T., Claeys, T., Claes, C., Vandevelde, S., \& Crucke, S. (2015). Does Performance Management Affect Nurses Well-Being? Evaluation and Program Planning, 49, 98-105.

19. Derue, D. S., Nahrgang, J. D., Wellman, N. E. D., \& Humphrey, S. E. (2011). Trait and behavioral theories of leadership: An integration and meta-analytic test of their relative validity. Personnel psychology, 64(1), 7-52.

20. Diamantidis, A., \& Chatzoglou, P. (2019). Factors Affecting Employee Performance: An Empirical Approach. International Journal of Productivity and Performance, 68(1), 171-193.

21. Emmerling, R., Boyatzis, R. E., \& Emmerling, R. J. (2012). Emotional and social intelligence competencies: cross cultural implications. Cross Cultural Management: An International Journal, 19(1), 4-18.

22. Farh, J. L., Hackett, R. D., \& Liang, J. (2007). Individual Level Cultural Values as Moderators of Perceived Organisational Support Employee Outcome Relationships in China: Comparing The Effects of Power Distance and Traditionality. Academy of Management Journal, 50(3), 715-729.

23. Gu, J., Wang, G., Liu, H., Song, D. and He, C. (2018). Linking Authoritarian Leadership to employee creativity: The influences of leader- member exchange, team identification and power distance. Chinese management Studies, 12(2), 384-406.

24. Gurbuz, S. (2009). The effect of High Performance practices on employees' job satisfaction. Journal of School of Business Administration, 110-123. 
25. Harms, D., Hansen, E. G., \& Schaltegger, S. (2013). Strategies in sustainable supply chain management: an empirical investigation of large German companies. Corporate social responsibility and environmental management, 20(4), 205-218.

26. Harms, P. D., Wood, D., Landaya, K., Lester, P. B., Lester, G. V. (2018). Auticratic leaders and authoritarian followers revisited: A Review and agenda for the future. The Leadership Quarterly, 29, 105-122.

27. Harvey, G. (2008). Writing with Sources: A Guide for Students. IndianaPolis.

28. Hinkelman, K., and Witschei, H. A. (2014). Applying Research Methodologies. Switzerland: Meta.

29. Hong, J., Zhang, Y. and Ding, M. (2018). Sustainable supply chain management practices, supply chain dynamic capabilities and enterprise performance. Journal of Cleaner production, 172, 3508-3519.

30. Igbaekemen, G. O., \& Odivwri, J. E. (2015). Impact of leadership style on organization performance: A critical literature review. Arabian Journal of Business and Management Review, 5(5), 1-7.

31. Iqbal, N., Anwar, S., \& Haider, N. (2015). Effect of leadership style on employee performance. Arabian Journal of Business and Management Review, 5(5), 1-6.

32. Kalu, D.C., and Okpokwasili, N. P. (2018). Impact of Autocratic leadership style on Job Performance of Surbodinates in Academic Libraries in Port harcot, RiverState Nigeria. International Journal of Research-Granthaalayah, 6(10), 212-220.

33. Khoreva, V., \& Wechtler, H. (2018). HR practices and employee performance: the mediating role of well-being. Employee Relations, 40(2), 227-243.

34. Kimberlin, C. L., \& Winterstein, A. G. (2008). Validity and reliability of measurement instruments used in research. American journal of health-system pharmacy, 65(23), 2276-2284.

35. Kwaako, L., Laribik, J., James, K., Kumah, V., \& Patience, K. (2012). Improving Tax Revenue in The Informal Sector (An Evidence of Internal Revenue Services). Doctoral Dissertation.

36. Li, C., Naz, S., Khan, M. A. S., Kusi, B., \& Murad, M. (2019). An empirical investigation on the relationship between a high-performance work system and employee performance: measuring a mediation model through partial least squares-structural equation modeling. Psychology Research and Behavior Management, 12, 397.

37. Li, Y., \& Sun, J. M. (2015). Traditional Chinese Leadership and Employee Voice Behaviour: A Cross Level Examination. The Leadership Quality, 172-189.

38. Li-jun, Y. A. N. G. (2016). The Supply-Side Reform of Circulation Enterprises based on Supply Chain Optimization. China Business and Market, (4), 4.

39. Lohr, S. (2013). Big data, trying to build better workers. The New York Times, 21.

40. Ludeke, S. (2016). Authoritarianism: Positives and negatives. In V. Zeigler-Hill \& D. K. Marcus (Eds.), The dark side of personality: Science and practice in social, personality, and clinical psychology (p. 231-250). American Psychological Association.

41. Makanyeza, C., \& Chikazhe, L. (2017). Mediators of the relationship between service quality and customer loyalty. International Journal of Bank Marketing, 35(3), 540556.

42. Mastrangelo, A., Eddy, E., \& Lorezent, S. (2014). The Relationship Between Enduring Leadership and Organisational Performance: Leadershhip and Organisational Development Journal, 35(7), 590-604.

43. Miles, R. E. (2007). Innovation and leadership values. California Management Review, 50(1), 192-201. 
44. Mukonoweshuro, \& Sanagura. (2016). The Role of Servant Leadership and Emotional Intelligence in Manaerial Performance in a Commercial Banking Sector in Zimbabwe. Banks and Banks System, 11(3), 94-108.

45. Ndlovu, I., \& Sigola, M. (2013). Benefits and Risks of E-Banking: Case of Commercial Banking in Zimbabwe. The International Journal of Engineering And Science, 2(4), 3440.

46. O'Leary, Z. (2005). Researching real world problems: A guide to methods of inquiry. London: SAGE.

47. Pacific, P. A. Organizational vs. Technical and Behavioral Competencies. (2018, May 17). $\quad$ Retrieved from: https://www.profilesasiapacific.com/2018/05/17/organizational-technicalbehavioral-competencies/

48. Patel, V. V. (2015). Exploratory Factor Analysis: Using SSPS. Advanced Data Analysis for Business Research using statistical packages. Gujarat Technological University.

49. Paulraj, A., Chen, I. J., \& Blome, C. (2017). Motives and performance outcomes of sustainable supply chain management practices: A multi-theoretical perspective. Journal of Business Ethics, 145(2), 239-258.

50. Pope, C., and Mays, N. (2000). Qualitative research in health care. London: BJM Books.

51. Pulakos, E. D. (2004). Performance Management: Effective Practice Guidelines: A Roadmap for developing, implementing and evaluating performance management systems. Alexadria: Society for Human Resources Mangement (SHRM).

52. Salvato, C., \& Rerup, C. (2011). Beyond Collective Entities: Multilevel Research on Organisational Routines and Capabilities. Journal of Management, 37, 468-490.

53. Saunders, M., Lewis, P. and Thornhill, A. (2007). Research Methods for Business Students. 4th Edition. London: Prentice Hall.

54. Sendawula, K. Kimuli, S., Juma, B. and Muganga, G. N. (2019). Training, Employee Management and Employee Performance: Evidence from Uganda's Health Sector. Psychology Research and Behaviour Management, 397-416.

55. Shen, Y., Chou, W. J., \& Schaubroeck, J. M. (2019). The roles of relational identification and workgroup cultural values in linking authoritarian leadership to employee performance. European Journal of Work and Organizational Psychology, 28(4), 498509.

56. Suharno, P., \& Despinur, D. (2017). The impact of work motivation and competence on employee performance through service quality in administrative staff of Universitas Negeri Jakarta, Indonesia. Russian Journal of Agricultural and SocioEconomic Sciences, 61(1).

57. Terglav, K., Ruzzier, M. K., \& Kaše, R. (2016). Internal branding process: Exploring the role of mediators in top management's leadership-commitment relationship. International Journal of Hospitality Management, 54, 1-11.

58. Van Esch, E., Wei, L. Q., \& Chiang, F. F. (2018). High-performance human resource practices and firm performance: The mediating role of employees' competencies and the moderating role of climate for creativity. The International Journal of Human Resource Management, 29(10), 1683-1708.

59. Walumbwa, F. O., Mayer, D. M., Wang, P., Wang, H., Workman, K., \& Christensen, A. L. (2011). Linking ethical leadership to employee performance: The roles of leadermember exchange, self-efficacy, and organizational identification. Organizational behavior and human decision processes, 115(2), 204-213. 
60. Wang, H., \& Guan, B. (2018). The positive effect of authoritarian leadership on employee performance: The moderating role of power distance. Frontiers in psychology, 9, 357.

61. Wang, P., \& Wang, S. (2018). What Role Does the Authoritarian Leadership and Benevolent Leadership Play in the Relationship Between Voice Behavior and Innovative Behavior? In 2018 3rd International Conference on Education, Sports, Arts and Management Engineering (ICESAME 2018). Atlantis Press.

62. White, B. (2000). Dissertation Skills for business and management students. Singapore: Send Less Press. 